\title{
A IMPORTÂNCIA DA FOTOGRAFIA PUBLICITÁRIA
}

\section{Paula Vieira ${ }^{1}$ \\ Leonardo Madson ${ }^{2}$ \\ Ana Carolina Marini ${ }^{3}$ \\ Sérgio Gurgel ${ }^{4}$}

Resumo: Este artigo apresenta uma análise sobre a importância da fotografia na publicidade, através da realização de um estudo sobre as melhores técnicas fotográficas para tal, a fim de demonstrar como as imagens interferem na venda e divulgação de produtos e como ela pode atrair e influenciar decisões. Por meio de pesquisas com consumidores e microempresários, os resultados obtidos foram que propagandas com imagens atrativas agradam o consumidor, resultando em maiores vendas, além de comprovar sua eficácia e importância.

Palavras-chave: Fotografia; Publicidade; Vendas.

\footnotetext{
${ }^{1}$ Fundação Valeparaibana de Ensino - Colégios Univap, Brasil. E-mail: paulafavieira@gmail.com.

2 Fundação Valeparaibana de Ensino - Colégios Univap, Brasil. E-mail: leonardo.madson@gmail.com.

3 Fundação Valeparaibana de Ensino - Colégios Univap, Brasil. E-mail: mariniturismo@gmail.com.

${ }^{4}$ Fundação Valeparaibana de Ensino - Colégios Univap, Brasil. E-mail: sgurgel@univap.br.
} 